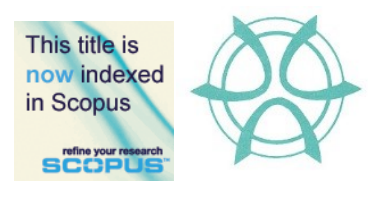

PLANNING MALAYSIA:

Journal of the Malaysian Institute of Planners

VOLUME 19 ISSUE 4 (2021), Page $257-268$

\title{
INVESTIGATING URBAN GROWTH BOUNDARY AS MECHANISM TO PLAN FOR SUSTAINABLE URBAN DEVELOPMENT
}

\author{
Narimah Samat ${ }^{1}$, Mohd Amirul Mahamud ${ }^{2}$, Mohammad Javad Maghsoodi \\ Tilaki ${ }^{3}$, Mohd Azmeer Abu Bakar ${ }^{4}$, Mou Leong Tan ${ }^{5}$, Norzailawati Mohd Noor ${ }^{6}$ \\ 1,2,3,4,5 Geoinformatic Unit, Geography Section, School of Humanities \\ UNIVERSITI SAINS MALAYSIA \\ ${ }^{6}$ Kulliyyah of Architecture and Environmental Design \\ INTERNATIONAL ISLAMIC UNIVERSITY MALAYSIA
}

\begin{abstract}
Urban encroachment into the peri-urban areas has blurred the borders between urban and rural areas. Thus, the urban growth boundary (UGB) has been used to encourage the sustainable development of cities and improve long-term planning efficiency. Studying the understanding of the UGB concept in ensuring sustainable development in Malaysia would be beneficial. This study aimed to investigate the perception and understanding of the UGB concept and function to achieve sustainable urban development. An online survey was conducted involving 82 experts, which comprised planners from PLANMalaysia and academicians in the field of urban planning. Results indicated that the perception of the UGB score was significantly greater by 1.16 than the normal score of 3 , which indicated that the experts agreed that UGB could improve the urban development. The findings also indicated that the existing planning policy and inclusion of UGB had protected agricultural and natural land; however, stricter and tighter borderless development should be conducted.
\end{abstract}

Keywords: Urbanization, Sustainable Urban Development, Urban Growth Boundary, Urban Containment Boundary

\footnotetext{
${ }^{1}$ Professor at Universiti Sains Malaysia. Email: narimah@usm.my
} 
Narimah Samat, Mohd Amirul Mahamud, Mohammad Javad Maghsoodi Tilaki, Mohd Azmeer Abu Bakar, Mou Leong Tan, Norzailawati Mohd Noor

Investigating Urban Growth Boundary as Mechanism to Plan for Sustainable Urban Development

\section{INTRODUCTION}

Agenda 11 of the United Nations Sustainable Development Goals (SDGs) is the Sustainable Cities and Communities, which called for a better way to manage cities because cities are hubs for economic development and social well-being for most people on Earth (UN, 2016). It is projected that the population in cities will rise to 5 billion by 2030, with a higher rate in developing nations (Easton, 2012; UN-Habitat, 2016; Samat, 2019). Yet, in most countries, cities only occupied less than $10 \%$ of their total land area. Therefore, proper planning and management practices must be available to deal with urbanisation issues and related challenges (UN, 2016). Moreover, heavily populated cities can threaten the nation if they are not planned and managed properly (Samat, 2019). Planning should take the current situation into account and predict the future development for their sustainability (Othman et al., 2021). However, efforts to control urban development are often faced with challenges due to the lack of understanding and scientific tools or methods to maintain municipalities within controlled city boundaries (Cilliers, 2015; Fertner et al., 2016).

To use scarce land resources effectively in satisfying urban demand, the urban form has been utilised to manage growth (Sharma, 2014). The urban form has been claimed to shape the urban layout and promoting sustainable urban development (Zivkovic, 2019). The compact urban form with a high-density mixed-use and intensified urban form is more sustainable than the sprawl type of urban growth (IEREK, 2016). Furthermore, urban expansions with designated growth boundaries have also been popularly used to ensure land demand and supply will be allocated sustainably (Tayyebi et al., 2014). Although several developed countries have used this approach to plan and control urban expansion (Chen, 2020), not much effort has been exerted in developing nations. Thus, a proper understanding of this concept is needed to be effectively used as a planning tool. Thus, this study aims to investigate the understanding of the concept of urban growth boundary (UGB) and the perceptions of experts on urban growth in Malaysia.

\section{RESEARCH BACKGROUND}

UGB and the urban containment boundary (UCB) are defined as proactive growth management tools which sought to contain, control, direct or phase growth to promote a compact, contiguous urban development (Tayyebi et al., 2014). Moreover, Mathur (2014) and Chen (2020) also added that UGB could help preserve farmland or environmentally sensitive land (including hill slopes and forests), guide urban development towards the central, and encourage denser development. Historically, these two approaches have been used in urban growth limits since the end of the $19^{\text {th }}$ century, where opposition started against the unregulated ribbon type of growth in England. In 1947, the Town and Country 
Planning Act allowed the local authority to incorporate green belt proposals in their development plan in England. Subsequently, numerous countries such as Great Britain (Gunn, 2007), Australia (Eddo, 2007), Iran (Tayyebi et al., 2014), India (Venkataraman, 2014) and Saudi Arabia (Aldalbahi and Walker, 2015) have successfully adopted the UGB as a way to curb urban sprawl and overcome related problems.

In the United States, UGB was used to control urban sprawl. Portland, Oregon has used this concept as a planning mechanism to plan and project future sustainable urban expansion to accommodate a 20-year forecast of housing needs and employment growth (Oregon Metro, 2018). Similarly, Melbourne, Australia also used a similar approach to ensure sustainable land use to accommodate future urban expansion (Cilliers, 2015). In the United States, more than 100 cities have adopted this concept. Portland, Oregon has been one of the most published cities which used this approach to plan future expansion. Its suitability in Asian cities was assessed by Venkataraman (2014) in the city of Bengaluru, India, which aimed to limit urban sprawl within the city.

Furthermore, Aldalbahi and Walker (2015) also have emphasised that limiting urban growth within a specific boundary has allowed the transportation services to keep up on demand and commuting becomes much shorter in the city of Riyadh, Saudi Arabia. The People's Republic of China's Town and Country Planning Act required the establishment of urban construction boundaries in Chinese city master and detail plans in 2006 (Long et al., 2009) and has inspired the attention of the Chinese Government for restricting the irrational urban sprawl, protecting the green space and ecological space from being developed (Zheng et al., 2017; Ren et al., 2020). Furthermore, Zheng et al. (2017) also emphasised that UGB can be utilised to design and enforce extensive planning policies and decision-making mechanisms, such as land-use zoning systems, thus mitigating the adverse effects of blind urban growth and encouraging sustainable development.

Despite many positive views that UGB/UCB has been seen to achieve sustainable urban development, this concept has also been debated. In Melbourne, much concern was shown over unchecked development within existing UGB, which can result in unsustainable land use (Birrell, 2005). The investigation by Dierwechter and Carlson (2007) also highlighted that UGB could worsen traffic congestion and economic unsustainability for urban, suburban and local governments. Furthermore, other issues criticising UGB included escalating land prices, a distraction from creative planning and its lack of regional division. It was supported by Mathur (2014) that the UGB is most likely to increase land prices, depending on housing demand and supply elasticity for its effect on property prices. 
Narimah Samat, Mohd Amirul Mahamud, Mohammad Javad Maghsoodi Tilaki, Mohd Azmeer Abu Bakar, Mou Leong Tan, Norzailawati Mohd Noor

Investigating Urban Growth Boundary as Mechanism to Plan for Sustainable Urban Development

Malaysia has started to adopt a sustainable development agenda back in 2001 when it became one of the national policy agendas within the Eight Malaysia Plan from 2001 to 2005 (Marzukhi et al., 2011; Adham et al., 2015). Furthermore, PLANMalaysia has developed a set of indicators which can be used to measure the development sustainability called the Malaysian Urban Indicators Network (MurniNet) system (Mun et al., 2019). This development was a national aspiration aimed at fulfilling the concept of sustainable development of the country (PLANMalaysia, n.d). Various initiatives have been conducted to achieve sustainable urban development where local municipal councils have played active roles in planning sustainable urban development. Among the initiatives are the Cleaner and Greener Penang initiatives by Pulau Pinang City Council, PJSmart City initiative by Petaling Jaya Municipal Council, Malaysia Smart City Programs by Ministry of Housing and Local Government and Green City Action Plan 2020 by Melaka State Government.

Cleaner and Greener Penang initiatives have proposed a way for Penang to restore the living environment in encouraging a cleaner and greener city (PPCC, 2017). It also improves the quality of life of Penangites by building a trilateral partnership with the state government, private sector company and community to empower the community to work closer towards a cleaner and greener Penang (PPCC, 2017). PJSmart City's initiative goals are to become a resilient and smart city by using technology to provide a cleaner, greener and more connected city (PJMC, 2017). Smart City programs have shown the government's effort to ensure which cities are smart and sustainable. This effort will leverage other national initiatives, such as the National Fiberization and Connectivity Plan (Ministry of Housing and Local Government of Malaysia, 2018).

Another initiative in Malaysia is the Green City Action Plan (GCAP), which seeks to transform into a low carbon city. Energy, transport and waste are important in the GCAP, among other projects, such as tourism and water management (Jamaludin and Sulaiman, 2018). GCAP prioritises the reduction of GHG emissions in the energy sector by preparing a comprehensive energy plan and implementing demonstration projects to reduce energy consumption (Melaka State Government, 2020). Although various initiatives have been conducted in planning for sustainable urban development, UGB/UCB can function as a mechanism in achieving sustainable urban development. This initiative was already outlined in the $2^{\text {nd }}$ National Urbanization Policy. Thus, this study aimed to investigate the understanding of the UGB and USG concepts in the context of Malaysia. 
PLANNING MALAYSIA

Journal of the Malaysia Institute of Planners (2021)

\section{MATERIALS AND METHODS}

This study explores the usage of UGB/UCB as mechanism for promoting sustainable urban development. The study used a quantitative survey, which involved asking the experts to answer a self-administered online questionnaire. The survey was conducted in English and Malay based on the respondents' preference, and the questionnaire required approximately 10 minutes to complete. Apart from providing their demographic information, participants responded to 12 statements which potentially reflected the perception of experts in urban planning in Malaysia on the suitability of UGB as a planning growth policy. Therefore, the online survey was conducted to measure the respondents' perception of urban growth in Malaysia and their understanding of the concept of UGB and how it can be used to plan and manage USG. Therefore, in the last section, the perception of those who understood the meaning of the UGB concept was considered. The scores were based on a five-point Likert scale (from $1=$ strongly disagree to $5=$ strongly agree).

The survey was conducted from 15 to 30 March 2020 using purposive sampling. The selected respondents were those who had worked or conducted research and teaching on planning-related sectors, such as PLANMalaysia and academicians in the field of urban planning. Those respondents are knowledgeable, experienced and are experts in urban planning, thus making the findings suitable in the context of planning in Malaysia (Utomo et al., 2018). Therefore, the 82 respondents participated in the survey is sufficient to provide an input for this study (Thordal-le Quement, 2016). Six statements were used to investigate the respondents' perceptions on urban expansion and planning policy in Malaysia. Moreover, six statements were used to measure the respondents' perception of urban growth boundary as a mechanism to achieve sustainable urban development.

Reliability tests were conducted to ensure the validity of the study. Results indicated that the Cronbach's alpha for UGB is $\alpha=0.719$ and USG is $\alpha$ $=0.706$. This indicated that the survey instrument was valid and reliable.

\section{FINDINGS AND DISCUSSIONS}

\section{Profile of the Respondents}

This study aimed to understand the perception of local experts on the UGB concept and the suitability of this concept in planning for sustainable urban development in the context of Malaysia. In total, 82 respondents aged 18 years and older answered the survey. Thus, all respondents have work experience in urban planning and development in Malaysia. Table 1 depicted the demographic characteristics of the respondents. Out of 82 respondents, slightly over $64 \%$ of the respondents were male. The majority of respondents were from 18 to 27 years old. 
Narimah Samat, Mohd Amirul Mahamud, Mohammad Javad Maghsoodi Tilaki, Mohd Azmeer Abu Bakar, Mou Leong Tan, Norzailawati Mohd Noor

Investigating Urban Growth Boundary as Mechanism to Plan for Sustainable Urban Development

This study aimed to identify perceptions on the suitability of UGB as a planning mechanism to achieve sustainable urban development in Malaysia. Table 1 shows that most respondents have had experience in the planning sector in Malaysia for more than five years (57.3\%). Only 25 respondents (30.5\%) had less than five years of experience in Malaysia's planning sectors.

Table 1: Respondents’ Demographic Characteristics

\begin{tabular}{llc}
\hline $\begin{array}{c}\text { Demographic } \\
\text { variables }\end{array}$ & \multicolumn{1}{c}{ Categories } & $\begin{array}{c}\text { Frequency (\%) } \\
\text { (Percentage) (n=82) }\end{array}$ \\
\hline Gender & Male & $53(64.6 \%)$ \\
& Female & $29(35.4 \%)$ \\
\hline Age & $18-27$ years old & $33(40.2 \%)$ \\
& $28-37$ years old & $16(19.5 \%)$ \\
& $38-47$ years old & $16(19.5 \%)$ \\
& $48-60$ years old & $16(19.5 \%)$ \\
& More than 60 years old & $1(1.2 \%)$ \\
\hline Education & Certificate or below & $1(1.2 \%)$ \\
& Diploma or Bachelor's Degree & $59(72.0 \%)$ \\
& Master or PhD Degree & $22(26.8 \%)$ \\
\hline Experience in & Less than 5 years & $25(30.5 \%)$ \\
& Between 5 and 10 years & $9(11.0 \%)$ \\
& Between 10 and 15 years & $12(14.6 \%)$ \\
& Between 15 and 20 years & $11(13.4 \%)$ \\
& More than 20 years & $15(18.3 \%)$ \\
& Not applicable & $10(12.2 \%)$ \\
\hline
\end{tabular}

\section{Perception of UGB in Malaysia}

Based on the previous analysis on reliability, five statements were used to investigate the respondents' perception of Malaysia's urban expansion and planning policy. Table 2 shows the descriptive statistics of the respondents' perceptions on UGB in Malaysia. The perceptions asked in the questions involved urban growth and existing policy, which guided urban planning and development in Malaysia. The mean values for all items were above 3, indicating that the respondents tend to agree with the statements and perceived that UGB is a useful concept to control USG in Malaysia.

As indicated in Table 2, planners agreed that UGB could manage urban spatial growth with a mean value of $3.91(S D=0.789)$. As to the second question on the ability of UGB to protect agricultural and natural land, the value of 4.16 indicated that the respondents had an overly strong tendency within their answer. 
Respondents also strongly agreed that UGB could be used to plan future urban expansion. The findings from the analysis further indicated that respondents strongly agreed on the role of UGB in planning future urban expansion. As stated in DPN2, UCB and UGB have become policy approaches at the national level to manage urban spatial growth in Malaysia (PLANMalaysia, 2016). Although this concept was yet to be implemented in Malaysia, it was piloted for the city of Kuantan, Pahang. Finally, respondents strongly agreed that UGB could be used to handle crisis situations such as virus outbreaks. For example, in handling diseases or viruses such as COVID-19, spatial connectivity through transportation hubs can easily be controlled if a boundary exists between urban and non-urban areas. Thus, the spatial diffusion of COVID-19 can easily be broken at the edge of the city (Neiderud, 2015, Samat, 2020).

In addition to descriptive statistics, the one-sample t-test was used to determine whether the sample mean comes from a distribution with a given mean and construct confidence intervals for the mean. Based on the summative score of perception of UGB, the result indicated that the perception on UGB score was statistically and significantly greater by $1.16(95 \% \mathrm{CI}, 1.06$ to 1.26$)$ than the normal score of $3, t(81)=22.996, p<0.01$.

Table 2: Descriptive Statistics of Perceptions of Respondents on UGB in Malaysia

\begin{tabular}{clcc}
\hline Item & Perception on UGB & Mean & SD \\
\hline UGB1 & $\begin{array}{l}\text { UGB has successfully been used to control urban spatial } \\
\text { growth. }\end{array}$ & 3.91 & 0.789 \\
\hline UGB2 & UGB can preserve natural and agricultural areas & 4.16 & 0.711 \\
\hline UGB3 & UGB can assist planners in directing urban future. & 4.32 & 0.564 \\
\hline UGB4 & $\begin{array}{l}\text { UGB can be used to ensure sustainable cities and } \\
\text { communities. }\end{array}$ & 4.26 & 0.562 \\
\hline UGB6 & $\begin{array}{l}\text { In crisis such as disease outbreak, UGB can also be } \\
\text { used to control spread of disease. }\end{array}$ & 4.15 & 0.669 \\
\hline
\end{tabular}

\section{Perception on Controlling USG}

The survey asked the respondents to rate their perceptions on controlling USG in Malaysia. As shown in Table 2, respondents agreed that urban growth in Malaysia cannot be controlled. The mean value of $2.82(S D=1.135)$ indicated that most respondents tends to disagree with that statement. Urban expansion has not encroached into agricultural land, which also has a low mean score of 2.06. It shows that most respondents disagreed with the statement. The findings has shown that proper planning and monitoring need to be conducted since Malaysia is experiencing rapid urbanisation. For example, 1n 2015, Malaysia's population was 31.4 million, with $74 \%$ of them residing in urban areas. However, in 2020, the population increased to 33.8 million, and $77 \%$ lived in urban areas. It was projected to reach 41.5 million in 2040, with $85 \%$ living in urban areas (Samat, 
Narimah Samat, Mohd Amirul Mahamud, Mohammad Javad Maghsoodi Tilaki, Mohd Azmeer Abu Bakar, Mou Leong Tan, Norzailawati Mohd Noor

Investigating Urban Growth Boundary as Mechanism to Plan for Sustainable Urban Development

2019). In Peninsular Malaysia, the size of the build-up area has increased from only 435,090 ha to 759,900 ha from 2001 to 2008 . In 2015, it increased further to $1,160,553$ ha (NPP, 2001; 2008; 2015; Samat, 2019). Although the built-up area only covered $8.8 \%$ of the total land area of Peninsular Malaysia, more than $74 \%$ of the population lived within this area. Thus, a systematic planning approach needs to be implemented to ensure that rapid expansion of urban areas does not have negative effects.

Table 3: Descriptive Statistics of perceptions of Controlling USG in Malaysia

\begin{tabular}{llcc}
\hline Item & Perception on controlling USG & Mean & SD \\
\hline USG1 & Urban growth in Malaysia can be controlled. & 2.82 & 1.135 \\
\hline USG2 & $\begin{array}{l}\text { Urban expansion in Malaysia has not encroached into } \\
\text { agricultural land. }\end{array}$ & 2.06 & .880 \\
\hline USG4 & Urban expansion is Malaysia is sustainable. & 3.21 & .782 \\
\hline USG5 & $\begin{array}{l}\text { Available policies and plans have managed to ensure } \\
\text { sustainable urban development. }\end{array}$ & 3.41 & .916 \\
\hline USG6 & $\begin{array}{l}\text { Malaysia has enough resources and policies to handle } \\
\text { the crisis in an urban area. }\end{array}$ & 3.28 & .959 \\
\hline
\end{tabular}

The findings also indicated that respondents tend to agree that existing urban planning policy and strategy have managed to ensure sustainable urban development with a mean score of 3.21. Furthermore, respondents also agreed that Malaysia has enough resources and policies to handle the crisis in an urban area, with a mean score of 3.28. Malaysia has been tested with the recent outbreak of COVID-19, which became a pandemic as announced by the World Health Organization on 11 March 2020. Thus, it is timely to reexamine the existing planning policy to ensure tighter control which has been placed on borderless development (Samat, 2020), such that UGB/UCB should be implemented (PlanMalaysia, 2016). The result of the one-sample t-test has shown that the perception on controlling USG score (Mean $=2.96, S D=0.638$ ) was not different from $(95 \% \mathrm{CI},-0.18$ to 0.09$)$ the normal score of $3, t(81)=-0.623, p>0.05$. Based on the study, experts agreed that UGB could be used towards achieving sustainable urban development. Thus, this concept should be put into practice where dynamic urban models such as the cellular automata model can be used to predict future need and location of land for development. Thus, UGB can be determined and monitor such development by taking the need of future generations into account.

\section{CONCLUSION}

Urban expansion and industrialisation in Malaysia have caused various socioeconomic and environmental issues in urban and rural areas (Utomo et al., 2018). Therefore, the spread of cities beyond their boundaries has caused a new realm 
of challenges for urban management about poverty, urban sprawl and social disorder. While a few studies emerged to understand the UGB concept and reveal the effect of UGBs on sustainable urban development in Malaysia, this study featured the contribution of UGB to evaluate the experts' perception about UGB to control USG for the protection of agricultural and natural land into the future of Malaysia. UGB and other urban land policies have contributed to Malaysia's USG. Still, the separation of their percentages in the direction of USG is a considerable issue that cannot be revealed through technical approaches. Thus, the study was conducted by looking at the experts' opinions quantitatively as researchers are advised to use judgmental data quantification to reduce bias and enhance the reliability of research findings (Bruce et al., 2008; Thordal-le Quement, 2016). However, findings from this study indicated that experts are aware that urban spatial growth has encroached on the urban fringe. Although they strongly believed that the existing policy and plans managed to ensure that sustainable urban development is achieved, previous studies indicated that the agricultural and natural land had been overtaken by the manufacturing and services sector (Utomo et al. 2018). Consistent with Long et al. (2015) and Zheng et al. (2017), experts believed that UGB could be used to manage USG in Malaysia. Although respondents demonstrated that Malaysia has adequate resources and policies to tackle challenges in urban and peri-urban areas, this study is in agreement with Samat (2020) which showed that the existing planning policy could be reevaluated to establish an accurate investigation for developing land beyond UCB. Nevertheless, this study was conducted without an in-depth analysis on sustainability, including development, considering the physical, social and environmental elements. A further study with an in-depth survey would probably reveal more concrete results.

\section{ACKNOWLEDGEMENTS}

The authors would like to thank the Ministry of Higher Education for funding this project under FRGS Grant No. 203/PHUMANITI/6711709. The authors also acknowledged the contributions from respondents who participated in answering the survey and reviewers for their constructive comments.

\section{REFERENCES}

Adham, K., Siwar, C. \& Bhuiyan, M. (2015). An Overview of Malaysian Government Initiatives on Sustainable Consumption and Production Practices. OIDA International Journal of Sustainable Development, 8(6), 3-32.

Aldalbahi, M. \& Walker, G. (2015). Attitudes and policy implications of urban growth boundary and traffic congestion reduction in Riyadh, Saudi Arabia. International Conference Data Mining, Civil and Mechanical Engineering (ICDMCME'2015) 
Narimah Samat, Mohd Amirul Mahamud, Mohammad Javad Maghsoodi Tilaki, Mohd Azmeer Abu Bakar, Mou Leong Tan, Norzailawati Mohd Noor

Investigating Urban Growth Boundary as Mechanism to Plan for Sustainable Urban Development
Feb.
$1-2$,
2015
Bali
(Indonesia) https://iieng.org/images/proceedings pdf/2526E0215016.pdf.

Bruce, N., Pope, D. \& Stanistreet, D. (2008). Quantitative Methods for Health Research: A Practical Interactive Guide to Epidemiology and Statistics. John Wiley \& Sons Ltd, Chichester

Chen, X. (2020). The Expansion of Urban Growth Boundary and Its Impact on Housing Affordability in the Portland Metropolitan Area, Oregon.

Cilliers, E.J. (2015). Rethinking urban growth boundaries: Following the transportation corridors, Land Use Management and Transportation Planning. WIT Transactions on State of the Art in Science and Engineering, Vol 86, https://doi.org/10.2495/978-1-84566-077-2/002.

Dierwechter, Y. \& Carlson, T. (2007). Effects of Urban Growth Boundaries on Residential Development in Pierce County, Washington. The Professional Geographer, 59(2), 209-220.

Easton, M. (2012). The great myth of urban Britain, BBC News 28 June 2012. Retrieved 18 April 2020, from https://www.bbc.com/news/uk-18623096

Eddo, C. (2007). Residential sub-market targeting by developers in Brisbane. Urban Policy and Research, 25(2), 257-274.

Fertner, C., Jørgensen, G., Nielsen, T.A.S. \& Nilsson, K.S.B. (2016). Urban sprawl and growth management - drivers, impacts and responses in selected European and US cities. Fut. Cit. \& Env. 2(9). https://doi.org/10.1186/s40984-016-0022-2

Gunn, S.C. (2007). Green belts: A review of the regions' responses to a changing housing Agenda, Journal of Environmental Planning and Management, 50(5), 595-616.

International Experts for Research Enrichment and Knowledge Exchange - IEREK. (2016). The compact city a sustainable urban form. Retrieved from 18 April 2020, from https://www.ierek.com/news/index.php/2016/08/03/compact-citysustainable-urban-form/

Department of Town and Country Planning Malaysia - PLANMalaysia. (2016). Dasar Perbandaran Negara Kedua Semenanjung Malaysia dan Wilayah Persekutuan Labuan, Kuala Lumpur, Jabatan Perancangan Bandar dan Desa, Malaysia.

Jamaludin, I.S. \& Sulaiman, N. (2018). Malaysia Resilient Initiatives: Case Study of Melaka into Resilient City, Planning Malaysia Journal, 16(1), 15-24.

Long, Y., Mao, Q.Z., \& Dang A.R. (2009). Beijing urban development model: Urban Growth analysis and simulation. Tsinghua Sci. Techno., 14, 782-749.

Long, Y., Han, H.Y., Tu, Y.C., \& Shu, X.F. (2015). Evaluating the effectiveness of urban growth boundaries using human mobility and activity record. Cities, 46, 76-84.

Marzukhi, A.M., Omar, D., Leh, O.L.H, Hamir, M.S \& Barghchi, M. (2011) Malaysian Urban Indicators Network: A Sustainable Development Initiative in Malaysia, European Journal of Social Sciences, 25(1), 77- 84.

Mathur, S. (2014). Impact of urban growth boundary on housing and land prices. Evidence from King County, Washington, Housing Studies, 29(1), 128-148.

Melaka State Government (2020). Green City Action Plan 2020 (GCAP). Retrieved 7 October 2020, from https://www.melaka.gov.my/ 
Mun, H.W., Yee, L.S, \& Eng, T.K. (2019). Mapping of literatures and indicators to Sustainable Development Goals. Journal of Sustainability Science and Management, 14(6), 179-191.

Neiderud, C.J. (2015). How urbanisation affects the epidemiology of emerging infectious disease, Infection, Ecology \& Epidemiology, 5, 27060.

National Physical Plan - NPP. (2001). PLANMalaysia. Retrieved 9 April 2020, from https://www.planmalaysia.gov.my/index.php/en/agensi/penerbitanplanmalaysia/r ancanganfizikal-negara

National Physical Plan - NPP. (2008). PLANMalaysia. Retrieved 9 April 2020, from https://www.planmalaysia.gov.my/index.php/en/agensi/penerbitanplanmalaysia/r ancanganfizikal-negara

National Physical Plan - NPP. (2015). PLANMalaysia. Retrieved 9 April 2020, from https://www.planmalaysia.gov.my/index.php/en/agensi/penerbitanplanmalaysia/r ancanganfizikal-negara

Oregon Metro. (2018). Urban Growth Report 2018. Retrieved 18 April 2020, from https://www.oregonmetro.gov/sites/default/files/2018/12/03/2018 UGRsummary-11282018 v2pdf

Othman, A.G., Hj Ali, K. \& Asli, W.M.F. (2021). Application of Geographic Information System (GIS) and Analytical Hierarchy Process (AHP) technique to study land use change in Pendang, Kedah, PLANNING MALAYSIA: Journal of the Malaysian Institute of Planners, 19 (2), 226 - 237.

Petaling Jaya Municipal Council - PJMC (2017). PJSmart City initiatives, Petaling Jaya. Retrieved 7 October 2020, from http://www.mbpj.gov.my/en

Pulau Pinang City Council - PPCC (2017). Cleaner and Greener Penang initiatives, Pulau Pinang. Retrieved 7 October 2020, from http://www.mbpp.gov.my/en/

Samat, N. (2019). Pembangunan tanpa sempadan di Malaysia: Persoalan kelestarian dan transformasi kawasan, Siri Syarahan Umum Pelantikan Profesor, Pulau Pinang: Penerbit USM.

Samat, N. (2020). Covid-19: Impak tanpa sempadan, kesalinghubungan, Berita Harian, Khamis 26 March 2020, Bil 527.

Sharma, S.N. (2014). Urban forms in planning and design, International Journal of Research, 1(1), 7-16.

Tayyebi, A., Perry, P.C. \& Tayyebi, A.H. (2014). Predicting the expansion of an urban boundary using spatial logistic regression and hybrid raster-vector routines with remote sensing and GIS, International Journal of Geographical Information Science, 28(4), 639-659.

Thordal-Le Quement, M. (2016). The (Human) Sampler's Curses. American Economic Journal: Microeconomics, 8(4), 115-148.

United Nations - UN (2016). Sustainable Development Goals, Goal 11: Make cities inclusive, safe, resilient and sustainable. Retrieved 18 April 2020, from https://www.un.org/ sustainabledevelopment/cities/

UN-Habitat (2016). World Cities Report 2016. Urbanisation and development: Emerging futures. Retrieved 18 April 2020, from http://wcr.unhabitat.org/wp-content/ uploads/2017/02/WCR-2016 
Narimah Samat, Mohd Amirul Mahamud, Mohammad Javad Maghsoodi Tilaki, Mohd Azmeer Abu Bakar, Mou Leong Tan, Norzailawati Mohd Noor

Investigating Urban Growth Boundary as Mechanism to Plan for Sustainable Urban Development

Utomo, C., Rahmawati, Y.\& Krestawan, I. (2018). Development of Urban Market Spatial for Highest and Best Use of Land Productivity and Sustainability, Planning Malaysia Journal, 16(1), 163-172.

Venkataraman, M. (2014). Analysing Urban Growth Boundary Effects on the City of Bengaluru. Economic and Political Weekly, 49(48), 54-61.

Zheng, Q., Yang, X., Wang K, Huang, L., Shahtahmassebi, A.R, Gan, M., \& Weston M.V. (2017). Delimiting Urban Growth Boundary through Combining Land Suitability Evaluation and Cellular Automata. Sustainability, 9, 2213.

Zivkovic, J. (2019) Urban Form and Function. In: Leal Filho W., Azeiteiro U., Azul A., Brandli L., Özuyar P., Wall T. (eds) Climate Action. Encyclopedia of the UN Sustainable Development Goals. Springer, Cham. https://doi.org/10.1007/978-3319-71063-1 78-1

Received: $11^{\text {th }}$ August 2021. Accepted: $13^{\text {th }}$ October 2021 